\title{
2 \\ Introducing Paul Dibb (2): An Enriching Experience
}

Chris Barrie

I am very pleased to have been asked to provide an introductory note about Emeritus Professor Paul Dibb AM. However, even though I regard Paul as a close friend, I possess nothing like the detailed knowledge of Allan Hawke, who has worked with Paul over many years and shared many triumphs and a few disappointments with him as well. Also, I am not sure what to make of a geographer who, at one time in his early years, may have thought that Australia was 'all desert'!

I joined The Australian National University's (ANU) Strategic and Defence Studies Centre (SDSC) in 2003 as a visiting fellow. This was principally because Paul encouraged, and arranged, the needful for me to do so. Since that time we have worked together on a range of projects and that work, as well as a number of social engagements, has given me an insight into a wonderfully complex and interesting world that revolves around Paul's interests, of which there are many!

Before coming to SDSC, however, my first meeting with Paul occurred just before the delivery of his highly regarded Review of Australia's Defence Capabilities (Dibb Review). At that time, in 1985, I headed up the Royal Australian Navy's Tactical School (RANTACS) in Sydney. Paul had been seconded from his position at SDSC to undertake the 
review but, as a relatively junior Navy officer at the time, I certainly knew that Paul was an important person who was to be treated with proper respect. The Navy 'positioning' team, headed by Captain Adrian Cummins, had decided that the way to make an impression on Paul about the importance of the Navy's ambitions would be to get him to RANTACS where we could demonstrate all the wizardry of a modern navy and persuade him that his review should underscore the critical part a navy should play in the nation's strategic affairs, in peace and in war.

My strong recollection of that day was that Paul asked some hard questions of the Navy team (and I was not sure that we put our right foot forward). More positively, though, it seemed to me that, despite being a person of serious consequence, Paul was easy to get on with.

As history now records, the Dibb Review made a great deal of the critical importance of Australia's maritime approaches and the role a competent and properly structured navy and air force would play in providing the essential elements of the nation's defence.

Since that meeting I watched from the sidelines as Paul took on various other important responsibilities in the Defence organisation, including the preparation of the 1987 White Paper on The Defence of Australia. While I was unclear on the detailed responsibilities of these roles, I could not fail to observe that Paul was moving into increasingly more important positions as time went on ...

It was in the later years of my own career that I came to understand the nature and quality of the work in which Paul was engaged; it seemed he was successful in undertaking whatever task the government or secretary of the day wanted done! But, I knew very little about his work at the university.

In 2002 I retired to Oxford for just over 12 months after moving from being the Chief of the Defence Force, leaving Allan Hawke in charge of things at Defence. But, after 12 months of running down a sizeable portion of my pension lump sum in Oxford, I contacted Paul to see whether or not I could return to Canberra and perhaps work at SDSC. For me this would see a transition away from strategic leadership issues to taking a closer interest in strategic matters in Australia. It also goes without saying, I guess, that the events of 2003, 
which centred on the invasion of Saddam Hussein's Iraq, transformed many of our assumptions about the way in which we might manage our relationships with a wider world.

My proposal was taken on with considerable enthusiasm, which as I came to learn over the following years - is typical of the Dibb approach to those things in which he is interested or that challenge him. So it came to be that I was able to take up a visiting fellowship with SDSC in December 2003.

What have I discerned about Paul from that time?

Well, first of all, how lucky have we been in Australia to have the talents of 'a lad from Yorkshire' working on strategic affairs and in our intelligence community? His achievements in Australia almost certainly could not have been matched by a similar career if he had remained in the United Kingdom. To put it bluntly, Paul was simply born on the wrong side of the tracks! We were also fortunate that he came to Australia early enough in his career to carve out a special niche for his skills and talents.

Having been recruited in the United Kingdom to work in the Department of Overseas Trade as a young man, it was not long before he began to leave his mark. In all this time he has worked assiduously to build a reputation of extraordinary significance: as an academic, as a strategist, and as an intelligence czar.

After becoming a highly qualified and effective public servant, Paul's impact on the making of public policy, especially in the defence field in the 1980s and 1990s, was superior, and yet he also carved out an outstanding career in academia through his work at SDSC, especially as head of Centre from 1991 to $2003 .^{1}$

It was Paul's deep experience as a policy maker that I am sure underpinned his determination to fight to secure and maintain the critically important work of SDSC when there were forces at work seeking to undermine him, and the work of the Centre, inside the academic bureaucracy that was ANU at the time. What is highly

\footnotetext{
1 This aspect of Paul's career is spelled out in Meredith Thatcher and Desmond Ball's A National Asset: Essays Commemorating the 40th Anniversary of the Strategic and Defence Studies Centre, Canberra Paper No. 165 (Canberra: Strategic and Defence Studies Centre, 2006).
} 
relevant to this part of the story was his steely offer to remove the SDSC from ANU campus and place it elsewhere if its position was seriously threatened by the forces of darkness.

In his recent history he has worked with the Association of Southeast Asian Nations (ASEAN) regional forum, served as adviser to the Defence SA Advisory Board, and been a consultant to ministers from both major parties, the departments of Defence and of Foreign Affairs and Trade (DFAT), companies and foreign missions.

Another aspect of Paul's deep commitment to his trade in the strategic studies field is underscored by his unwavering presence each year at The Australian National University's Kioloa Coastal Campus during which students in the Masters programs have an opportunity to bond together as a cohort and use this time to speak informally to the Centre's academic staff. Paul is admirably serious about this aspect of his academic life. On a lighthearted note, the coastal campus routine has been embellished by Paul's enthusiasm for a stop at the Nelligen pub, where a few dozen recently caught oysters are bought for later consumption, matched by fine wine and, if we are really lucky, Yorkshire chip butties! What I have seen indicates that Paul sees young people with potential as being worth his time in nurturing, encouraging and mentoring.

Finally, Paul speaks occasionally of dropping some of his workload. I appreciate that time pressures prompt this train of thought, but I have seen little evidence that he really means it. Instead, he continues to maintain a vigorous and punishing schedule of public lectures, advisory positions, and media publishing, either on his own cognisance or collaboratively.

Since coming to SDSC I have very much enjoyed sharing in Paul's love of good food and quality red wine, as well as hearing his perspectives on a raft of issues. As we mark Paul's long contribution to SDSC and the Australian defence discourse, highlighted in the articles in this collection, I believe we have all been enriched by the experience of working together in the company of such a fine intellect. 
This text is taken from Geography, Power, Strategy and Defence Policy: Essays in Honour of Paul Dibb, edited by Desmond Ball and Sheryn Lee, published 2016 by ANU Press, The Australian National University,

Canberra, Australia. 